\title{
Adaptation of Coenobita scaevola (Forskal) (Crustacea, Anemura) to terrestrial life in desert-bordered shore line
}

\author{
Y. Achituv* \& M. Ziskind \\ Department of Life Sciences, Bar Ilan University, Ramat Gan 52100, Israel
}

\begin{abstract}
Coenobita scaevola (Forskal) is a terrestrial hermit crab inhabiting shores of the Sinai Peninsula, where animals encounter severe conditions of high temperature, high radiation and low relative humidity. Adaptation of these crabs to such arid conditions was studied. The crabs are nocturnally active, taking refuge during the day in hiding places with milder conditions. Body temperature follows that of their hiding places, which is lower than that of the air. After ca 6 h exposure to direct radiation, the crabs die. Thermoregulatory ability is low. Water loss is lower in shelled crabs, higher in crabs without shell; the shell protects the abdomen from desiccation. Freshly killed crabs evaporate less than live crabs, suggesting that evaporation from live crabs is not a purely passive process. Gill surface area is small in comparison with aquatic crabs. Aquatic oxygen consumption is 1.4 times higher than aerial. Unlike other Coenobita spp. which inhabit sites distant from the sea, and in spite of successful adaptation to terrestrial life, Coenobita scaevola does not penetrate far inland: in desert conditions it depends on the sea for its only water source.
\end{abstract}

\section{INTRODUCTION}

Hermit crabs are essentially marine animals, although some pagurids have invaded the intertidal zone taking shelter during low tide under stones, in crevices, or in tide pools. Hermit crabs of the family Coenobitidae have succeeded in invading the terrestrial environment. This family is distributed in tropical regions of the Indo-Pacific coasts and in the Carribean Islands of the Atlantic. The coenobitid Birgus latro is regarded as the most terrestrial of all crabs (Edney 1960), being found in areas with tropical vegetation and returning to the sea only for reproduction. The abdomen of this animal has lithified sclerites, obviating in adult crabs the necessity of using a shell for protection. The gills are reduced and the lining of the branchial chamber is used for gaseous exchange (Harms 1932, Edney 1960, Cameron 1981). Coenobita rugosus from the coast of Somalia spend long periods inland in the bush (Vannini 1976). In C. clypeatus from the Carribean Islands, a population of adult hermit crabs is found several $\mathrm{km}$ inland; it uses fresh water as its water source and migrates to the sea for reproduc-

\footnotetext{
- Addressee for correspondence
}

tion (deWilde 1973). Ripe eggs are released over the wet stones and washed into the sea by the tide. $C$. brevimanus from the Enewetak Atoll lives in wooded areas and within heavy vegetation, and uses fresh and brackish water as its water source. $C$. cavipes and $C$. perlatus drink sea water as well as brackish water (Gross \& Holland 1960, Gross et al. 1966).

Coenobita scaevola (Forskal) are found along the shores of the Red Sea. At El-Ghardaqa they are found from between tide marks up to $25 \mathrm{~m}$ from the high tide line. During the day they dig as deep as $15 \mathrm{~cm}$ into the sand or crawl into reef cavities. They fill their shells with sea water and feed on Sargassum weeds (Magnus 1960, Niegerman 1968). Volker (1967) studied shell selection behavior of C. scaevola in El-Ghardaqa and showed that the most common shells used were those of Turbo and Galeodes, the most common gastropods in the area. Volker (1969) also studied the morphology of the chelae and pleopods which make up the 'operculum' of the shell inhabited by $C$. scaevola.

Along eastern shores of the Sinai Peninsula (western shores of the Gulf of Elat) this species is found only in the south. On sandy beaches it digs into the sand during day time, and on rocky shores it crawls into crevices between rocks (Fishelson 1971). The most 
common shells used by $C$. scaevola on these shores are those of Polinices mammilla (pers. obs.).

When invading the terrestrial environment, Coenobita scaevola encounters desert conditions which differ considerably from those encountered by other species of Coenobita. Average air temperature during hot hours of the day $(10: 00$ to 14:00 h) in July-August in Elat is 40 to $41^{\circ} \mathrm{C}$, but temperatures as high as $47^{\circ} \mathrm{C}$ were also recorded (Ron 1967). Radiation at this time of day is $1.35 \mathrm{Cal} \mathrm{cm}^{-2} \mathrm{~min}^{-1}$ (Meteorological service data); radiated surface of sand reaches a temperature of 55 to $60^{\circ} \mathrm{C}$ (pers. obs.). Humidity is low due to dominant north winds blowing from the desert. Rain is rare and mean annual precipitation is only $17 \mathrm{~mm}$ (average value for Dahab calculated from Kesler 1982). There are no rivers or fresh-water sources along the Sinai Peninsula coasts. No bush or dense vegetation is found along the coast of Sinai, except for the mangal regions

The present study was performed in order to understand some aspects of the adaptation of Coenobita scaevola to terrestrial life in desert conditions. Capacity for thermoregulation, rate of water loss by evaporation, and adaptation of the respiratory system to aerial respiration were evaluated.

\section{MATERIALS AND METHODS}

Animals. Specimens of Coenobita scaevola were collected at Ras-Burka or at Shura-el-Gharqana, both on the western shores of the Sinai Peninsula. Only specimens inside shells of Polinices were collected, and ovigerous females were discarded. In the laboratory, the crabs were kept in a terrarium $(60 \times 60 \times 80 \mathrm{~cm})$, lined with sand on which pieces of tile were provided as hiding places. Sea water for drinking, and boiled eggs and vegetables as food were supplied and changed every second day. The terrarium was kept at room temperature $\left(25^{\circ} \mathrm{C}\right)$. Under these conditions, the animals were healthy and active, and mortality was very low. Food was consumed and faeces were found in the terrarium. The crabs were kept in the laboratory for more than half a year; however during this time they did not moult.

Temperature. Temperature was measured with an accuracy of $\pm 0.1 \mathrm{C}^{\circ}$ using precalibrated 45 SWG copper-constantan thermocouples (Dural Plastics). In the field, temperature was recorded at Shura-el-Gharqana, Ras-Muhamad and Ras-Burka using a Bat $8 \mathrm{~B}$ portable digital thermometer (Bailey Instruments) and in the laboratory by a Speedomax multipoint recorder with AZAR modules (Leeds \& Northrop). Thermocouples were fastened by dental cement to the crabs at 3 points: (1) outside the shell, isolated from it by a thin piece of wood: this probe measured the immediate ambient temperature $\left(\mathrm{T}_{a}\right)_{i}(2)$ inside the shell $\left(\mathrm{T}_{\mathrm{in}}\right)_{i}$ (3) through a hole in the dorso-lateral side of the carapace: this thermocouple measured the body temperature $\left(T_{b}\right)$. In the field, air temperature $10 \mathrm{~cm}$ above the sand and close to the crabs' refuge was also recorded $\left(T_{a i r}\right)$. Crabs were collected during the night, then attached to the thermocouples and released in the morning, being allowed to hide or dig in the sand freely. In situ temperature was recorded at Shura-el-Gharqana in individuals that had dug into the sand at a distance of 10 to $20 \mathrm{~m}$ from the high water line. At Ras-Burka and Ras-Muhamad temperature was measured in crabs hidden among the rocks or in crevices in the rocks. Temperature was also measured on crabs which were kept in clear PVC wire cages $(10 \mathrm{~cm}$ diameter, $5 \mathrm{~cm}$ height) and exposed to solar radiation, as well as in crabs protected from direct solar radiation, but exposed to air temperature, outside the shelter.

In the laboratory, temperature was measured in an open flow system (Shkolnik \& Borot 1969). Air flowing at $150 \mathrm{~cm}^{3} \mathrm{~min}^{-1}$ was dried on a silca gel column and then passed through glass tube spirals to a glass cylinder containing the crabs. Spiral and cell were immersed in a water bath heated to $40^{\circ} \mathrm{C}$. 14 crabs were used for laboratory experiments. Temperature was first measured in crabs with shells; at least $24 \mathrm{~h}$ later they were taken out of their shells and their temperatures were measured again under the same conditions. Temperature changes in crabs freshly killed by injection of $0.2 \mathrm{ml}$ of concentrated formaldehyde were also measured.

Water loss. Rates of water loss of live Coenobita scaevola with and without shells, and of freshly killed animals with and without shells, were estimated. Water losses were estimated in an open flow system similar to that used for temperature measurement. The rate of air flow was $100 \mathrm{~cm}^{3} \mathrm{~min}^{-1}$; temperature of the water bath was $40^{\circ} \mathrm{C}$. Water was collected in dry, preweighed omega-shaped glass tubes submerged in an alcohol freezing bath (Schmidt-Nielsen \& SchmidtNielsen 1950); the tubes were changed every $20 \mathrm{~min}$. Crabs were weighed at the beginning and end of each experiment. After each experiment the crabs were dried for $24 \mathrm{~h}$ at $105^{\circ} \mathrm{C}$ for estimation of their total water content.

Gill surface area. A modification of the method described by Gray (1957) was used. Each gill was divided into groups containing gill lamellae of similar size. Isolated gill lamellae were placed in a projection microscope (Reichart). The outline of the gill lamellae was traced on paper laid on the microscope screen, then cut and weighed. Several gill lamellae were weighed. For calibration, a rectangular piece of paper, of the same quality, equivalent to a $1 \mathrm{~mm}^{2}$ area was cut 


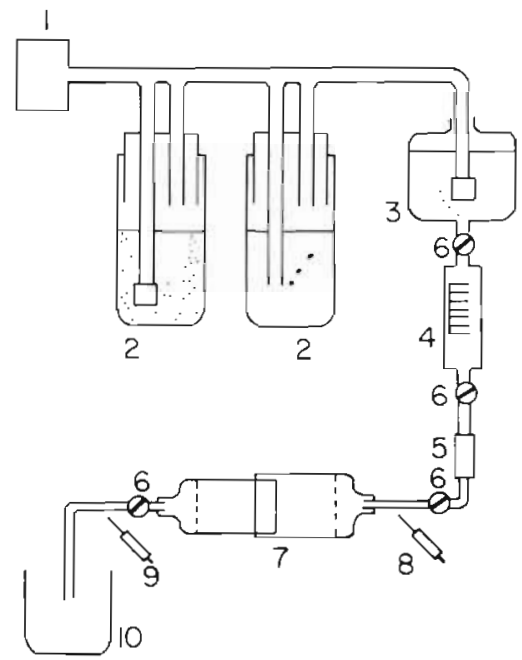

Fig. 1. Scheme of open-flow system used for measurement of aquatic oxygen uptake. 1: air pump; 2: air saturation bottles; 3: water reservoir; 4: Voluset buret; 5: helix infusion flow regulator; 6 : valves; 7 : measurement chamber; 8 ; syringe for inflow sample; 9: syringe for outflow sample; 10: water collecting jar

and weighed. Mean area of both sides of a single lamella of a particular size group was calculated and multiplied by number of gill lamellae of the same size. The total gill area was then calculated.

Oxygen uptake. $\mathrm{O}_{2}$ uptake was measured in crabs weighing 5 to $12 \mathrm{~g}$. Prior to measurement crabs were not fed for $48 \mathrm{~h}$ and were kept in the dark, in the container used for $\mathrm{O}_{2}$ uptake measurements. All measurements were made at $25^{\circ} \mathrm{C}$ and at the same time of day. Aerial respiration was measured in a home-made volumetric respirometer, based on the Gilson respirometer. The metabolic chamber was connected to a compensation chamber via a Gilson volumometer. The system was left for equilibration with ambient temperature for $1 \mathrm{~h}$. Measurements were taken every $15 \mathrm{~min}$ for $6 \mathrm{~h}$; an empty system was measured as a control.

Oxygen uptake in water was measured in an openflow system (Fig. 1), in which the flow of air was saturated with water and was bubbled into a sea-water reservoir. A constant volume of sea water regulated by a set of valves (Voluset Buret and helix infusion flow regulators) passed through a cylinder in which the crabs were kept. Water samples were taken simultaneously, every $15 \mathrm{~min}$ for $6 \mathrm{~h}$, at the entrance and exit of the metabolic chamber. Partial pressure of oxygen in the water was determined with a $\mathrm{pH}$ Blood Gas analyser (Instrumentation Laboratory, Inc.) and converted to its concentration in water $(\mathrm{v} / \mathrm{v})$. Oxygen uptake was then related to animal mass.

\section{RESULTS}

\section{Temperature and water relations}

Fig. 2 \& 3 represent examples of in situ measurements of the daily temperature changes in 2 out of 20 specimens measured; in Fig. 2 of a crab that was buried in sand at Shura-el-Gharqana, in Fig. 3 of a crab hidden in a crevice in a rock at Ras-Muhamad. Due to harsh conditions, not all thermocouples were functioning in all individuals for the entire period of measurement. Results presented in these figures are those showing the most complete picture; all specimens observed showed identical patterns of temperature changes.
Fig. 2. Coenobita scaevola. Selected in situ measurements of daily temperature changes of an individual buried in sand at a depth of $15 \mathrm{~cm}$ at Shura-el-Gharqana. (O) air temperature $10 \mathrm{~cm}$ above sand level; ( $)$ ambient temperature $(\bullet)$ body temperature; $(\Delta)$ temperature inside the shell

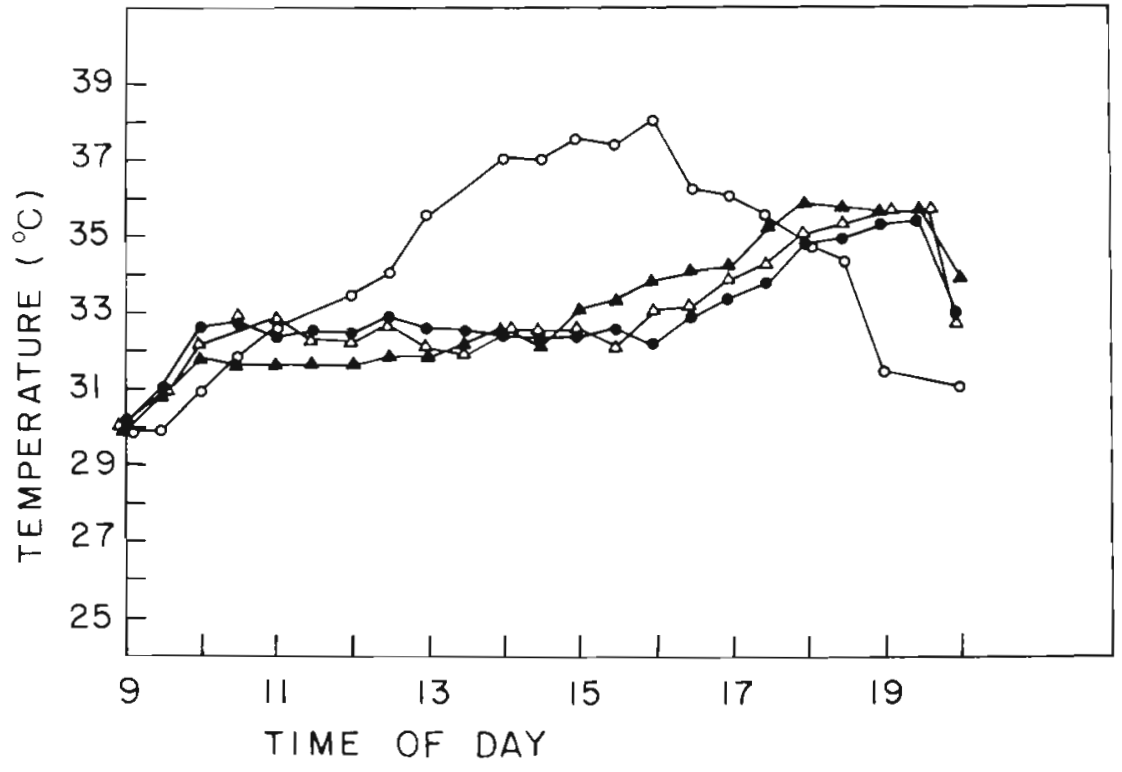




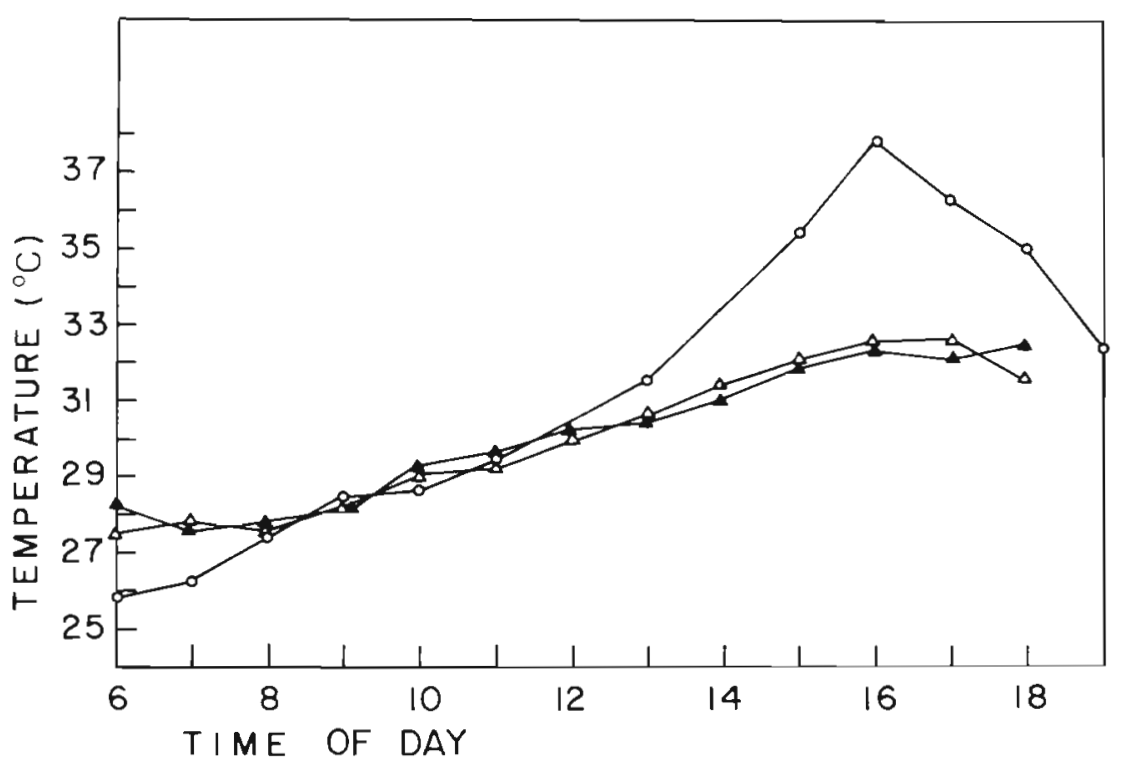

Fig. 3. Coenobita scaevola. Representative in situ measurements of daily temperature changes of an individual hidden in a rock crevice at Ras-Muhamad. (O) air temperature outside the crevice; (४) ambient temperature; ( $\Delta$ ) body temperature
In all cases observed, temperature inside the shell was identical to body temperature, $T_{i n}=T_{b}$. In crabs buried in sand at a depth of about $20 \mathrm{~cm}$, the body temperature and the temperature outside the shell differed by only $0.3 \pm 0.2 \mathrm{C}^{\circ}$; thus, body temperature followed that of the ambient. From the morning up to 16:00 $\mathrm{h}$, both air temperature and temperature inside the burrow increased simultaneously, but that of the burrow remained $5 \mathrm{C}^{\circ}$ lower. Sand surface temperature sometimes reached $54{ }^{\circ} \mathrm{C}$ at 13:00 h. After 16:00 h a decline in air temperature was observed, while temperature inside the burrow still continue to increase. At
16:00 $\mathrm{h}$ the difference between air temperature and temperature inside the crevice reached $5.2 \mathrm{C}^{\circ}$. After sunset, at about 18:00 h, the crabs left their burrows. In crabs hidden in crevices similar temperature relations were found. The difference between ambient and body temperatures is small and insignificant $\left(0.1 \pm 0.4 \mathrm{C}^{\circ}\right)$.

Fig. 4 shows the temperature changes of a representative specimen exposed to solar radiation and of a selected specimen protected from radiation but exposed to ambient temperature and relative humidity at ground level. Protected specimens show temperature patterns similar to those shown by specimens in

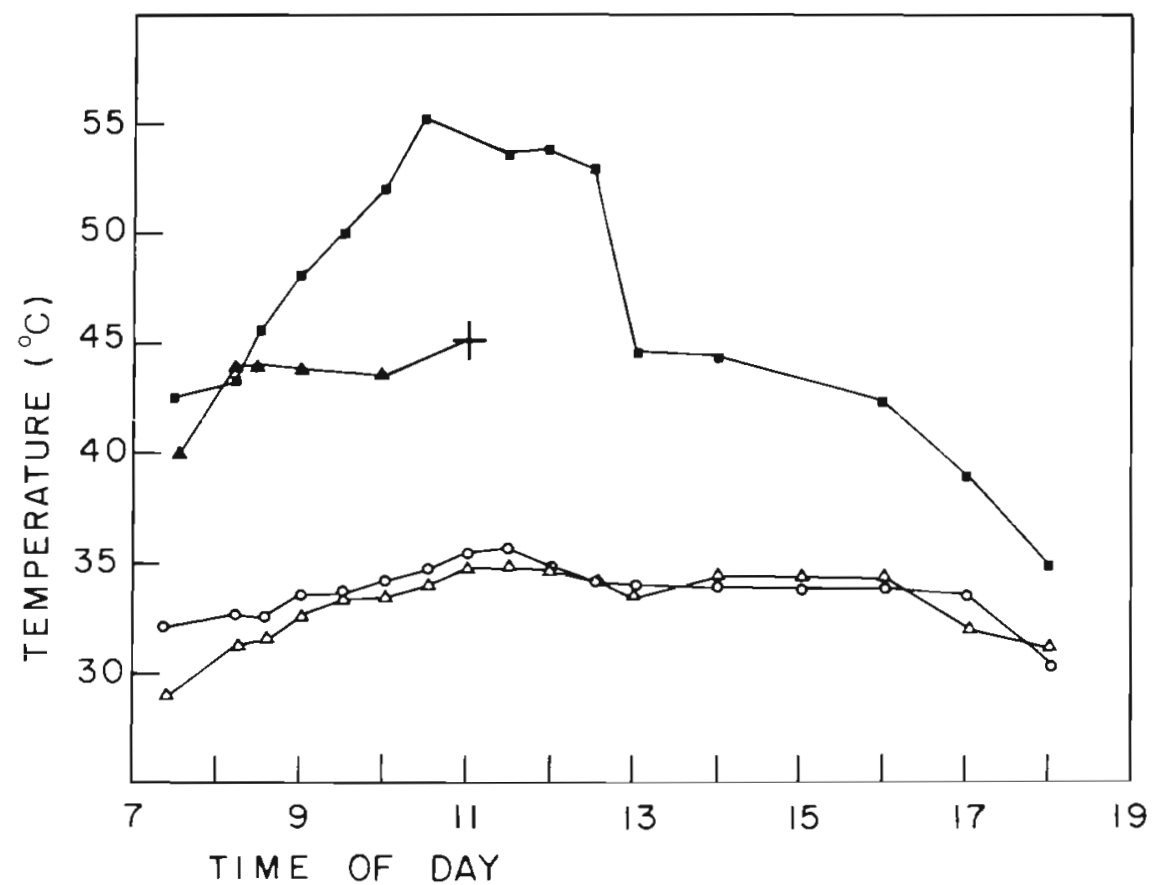

Fig. 4. Coenobita scaevola. Selected measurements of temperature changes in an individual exposed to direct solar radiation compared to an individual out of a refuge but protected from direct radiation. (O) air temperature; ( $\square$ ) sand surface temperature; ( $\mathbf{\Lambda}$ ) body temperature of an animal exposed to radiation; $(\Delta)$ body temperature of a protected animal $(+)$ time of death 
Table 1. Coenobita scaevola. Effect of direct solar radiation on body temperature of 6 individuals. Crabs were exposed to radiation at Shura-el-Gharqana in July. Time of day, duration of exposure to radiation, body temperatures of individuals, air temperature and sand temperature prior to death are presented. Data for 2 control specimens kept in shade are also presented.

These specimens did not die and times and body temperatures indicated are maximal values reached

\begin{tabular}{|c|c|c|c|c|c|c|}
\hline & & $\begin{array}{l}\text { Time } \\
\text { of day }\end{array}$ & $\begin{array}{c}\text { Duration of } \\
\text { exposure } \\
h\end{array}$ & $\begin{array}{c}\text { Body } \\
\text { temperature } \\
{ }^{\circ} \mathrm{C}\end{array}$ & $\begin{array}{c}\text { Air } \\
\text { temperature } \\
{ }^{\circ} \mathrm{C}\end{array}$ & $\begin{array}{c}\text { Sand } \\
\text { temperature } \\
{ }^{\circ} \mathrm{C}\end{array}$ \\
\hline Exposed crabs & $\begin{array}{l}1 \\
2 \\
3 \\
4 \\
5 \\
6\end{array}$ & $\begin{array}{l}10: 30 \\
11: 00 \\
12: 30 \\
12: 30 \\
13: 00 \\
13: 00\end{array}$ & $\begin{array}{l}5.5 \\
6.0 \\
7.5 \\
7.5 \\
8.0 \\
8.0\end{array}$ & $\begin{array}{l}45.2 \\
44.6 \\
42.0 \\
45.7 \\
45.0 \\
44.3\end{array}$ & $\begin{array}{l}34.3 \\
35.2 \\
34.0 \\
34.0 \\
33.7 \\
33.7\end{array}$ & $\begin{array}{l}50.7 \\
51.7 \\
54.2 \\
54.2 \\
54.2 \\
54.2\end{array}$ \\
\hline Control crabs & $\begin{array}{l}1 \\
2\end{array}$ & $\begin{array}{l}14: 00 \\
14: 30\end{array}$ & $\begin{array}{l}9.0 \\
9.5\end{array}$ & $\begin{array}{l}35.2 \\
35.8\end{array}$ & $\begin{array}{l}33.8 \\
33.7\end{array}$ & $\begin{array}{l}53.3 \\
53.3\end{array}$ \\
\hline
\end{tabular}

situ; radiated specimens reached high temperatures and started to die at 10:00 $\mathrm{h}$; all 12 specimens exposed to direct radiation died between 10:00 and 12:30 h. The body temperatures of 6 crabs prior to death is shown in Table 1. Maximum temperature measured in intact specimens in the field, under natural conditions, was

Table 2. Coenobita scaevola. Temperature measurements in control conditions of living and freshly killed crabs, with and without shells. Temperatures presented are maximum and minimum values obtained after $60 \mathrm{~min}$ of exposure to $40^{\circ} \mathrm{C}$. $\mathrm{N}$ : number of crabs studied; $\mathrm{T}_{\mathrm{a}}$ : ambient temperature; $\mathrm{T}_{\mathrm{b}}$ : body temperature

\begin{tabular}{|c|c|c|c|c|}
\hline & $\mathrm{N}$ & $\begin{array}{c}\left(T_{a}-T_{b}\right) \\
\max .\end{array}$ & $\begin{array}{c}\left(\mathrm{T}_{a}-\mathrm{T}_{b}\right) \\
\text { min. }\end{array}$ & $\begin{array}{c}\left(T_{a}-T_{b}\right) \\
(\text { mean }) \pm S D\end{array}$ \\
\hline $\begin{array}{l}\text { Live animals } \\
\text { in shells }\end{array}$ & 14 & 2.6 & 0 & $1.4 \pm 1.0$ \\
\hline $\begin{array}{l}\text { Live animals } \\
\text { without shells }\end{array}$ & 14 & 5.6 & 0 & $2.3 \pm 1.9$ \\
\hline $\begin{array}{l}\text { Freshly killed } \\
\text { animals in shells }\end{array}$ & 2 & 0.9 & 0.7 & $0.75 \pm 0.7$ \\
\hline $\begin{array}{l}\text { Freshly killed } \\
\text { animals without } \\
\text { shells }\end{array}$ & 2 & 2.1 & 1.6 & $1.85 \pm 0.3$ \\
\hline
\end{tabular}

Table 3. Coenobita scaevola. Evaporative water loss under controlled conditions of both living and freshly killed crabs, with and without shells. Results are percent of total water content lost in $20 \mathrm{~min}$. N: number of crabs studied; $n$ : number of measurements

\begin{tabular}{|lrrr|}
\hline & N & n & $\begin{array}{c}\text { Water loss (\%) } \\
\pm \mathrm{SD}\end{array}$ \\
\hline Live animals with shells & 16 & 240 & $0.41 \pm 0.14$ \\
Live animals without shells & 7 & 112 & $0.46 \pm 0.12$ \\
Freshly killed animals with shells & 2 & 32 & $0.34 \pm 0.12$ \\
Freshly killed animals without shells & 2 & 32 & $0.42 \pm 0.16$ \\
\hline
\end{tabular}

only $40.4^{\circ} \mathrm{C}$. In all instances prior to death the crabs left their shells which continued to rise in temperature.

The ability to thermoregulate was studied under controlled conditions in flowing dry air at $40^{\circ} \mathrm{C} \pm$ $0.50 \mathrm{C}^{\circ}$ for $1 \mathrm{~h}$. Crabs with shells were compared to crabs without shells and to freshly killed crabs (Table 2). The difference in thermoregulation between crabs with and without shells was significant (Student t-test; $\mathrm{P}<0.05$ ).

Evaporative water loss as percentage of total water content is presented in Table 3. Percentage of water lost was measured over a period of $20 \mathrm{~min}$. Water was collected at intervals of $20 \mathrm{~min}$ : for each crab 14 to 18 measurements were made. Data are mean values of all measurements. The slopes of linear regression for cumulative water loss of specimens in their shells and for specimens without shells was 0.41 and 0.46 , respectively, which fits the mean values calculated; I was 0.99 for both lines $(\mathrm{P}<0.005)$.

Freshly killed crabs lose water at a lower rate than live crabs. The rate of water loss of dead crabs without shells was identical to that of live crabs with shells. The lowest water loss was found in dead crabs with shells.

The relation between weight of specimen and water loss was also calculated. The linear regression equations for these are $\mathrm{H}_{2} \mathrm{O}$ loss $=0.78-0.059 w \mathrm{w}$., for crabs

Table 4. Coenobita scaevola. Numbers of gill lamellae and gill surface areas for 4 individuals

\begin{tabular}{|c|c|c|c|}
\hline $\begin{array}{c}\text { Crab dry wt } \\
\mathrm{g}\end{array}$ & No. of gills & No. of gills $\mathrm{g}^{-1}$ & $\begin{array}{l}\text { Gill surf. area } \\
\mathrm{mm}^{2} \mathrm{~g}^{-1}\end{array}$ \\
\hline 8.4 & 630 & 75.2 & 120 \\
\hline 9.0 & 600 & 66 & 129.2 \\
\hline 10.9 & 691 & 63.4 & 123.2 \\
\hline 22.4 & 636 & 28.4 & 117.6 \\
\hline Mean $\pm S D$ & $636 \pm 37$ & & $122.5 \pm 5.02$ \\
\hline
\end{tabular}


in shells $(\mathrm{n}=16, \mathrm{r}=0.70)$ and $\mathrm{H}_{2} \mathrm{O}$ loss $=0.68-0.01 \mathrm{wt}$, ( $n=7, r=0.78$ ), for crabs without shells.

\section{Gill surface area}

The number of gills on each side is 10, of which 3 are rudimentary. Shape and size of gill lamellae differ along the gill's long axis. In the middle of the gills, lamellae are wider and heart-shaped, while at the tips they are slender and long. The relation between the crabs' weight and the surface area of the gills is presented in Table 4. Histological sections (Fig. 5) show that the cuticle is thicker at the perimeter of the gill leaflet and forms a rim with swellings at the dorsolateral margins (Fig 6).

\section{Oxygen consumption}

Results of oxygen uptake of $10 \mathrm{crabs}$ in air and when immersed in water are given in Table 5 . In water the crabs consumed 1.4 times more oxygen than in air. The variations in oxygen consumption were large: there were periods of quiet when oxygen consumption was very low and periods of high activity which were reflected by high oxygen consumption.
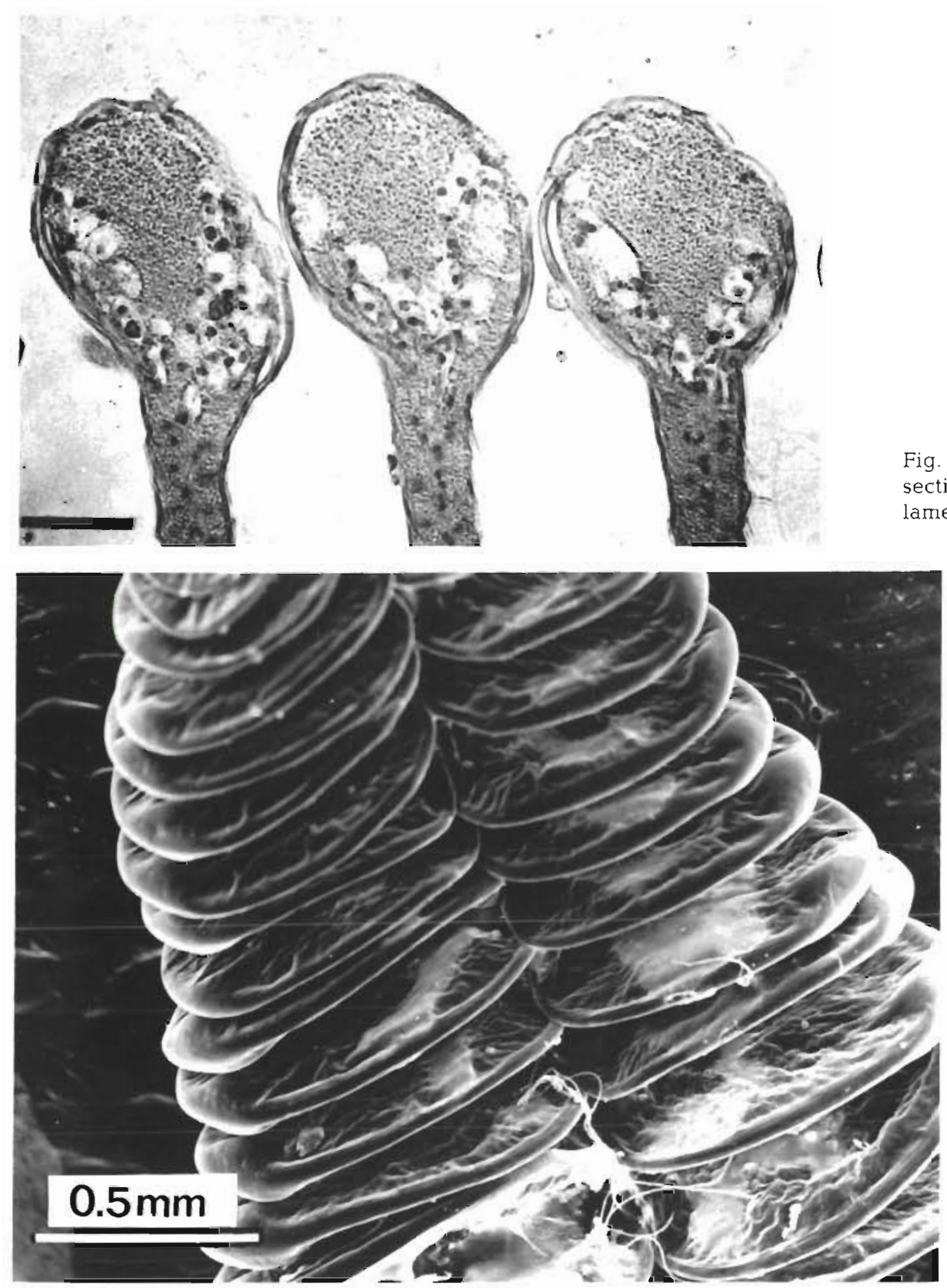

Fig. 5. Coenobita scaevola. Longitudinal section through the margins of gill lamellae showing swellings and thickening of the cuticle. Bar $=50 \mu \mathrm{m}$
Fig. 6. Coenobita scaevola. SEM photograph of gills showing swellings of dorso-lateral margins of gill lamellae 
Table 5. Coenobita scaevola. Aerial and aquatic oxygen uptake of $10 \mathrm{crabs}$ at $25^{\circ} \mathrm{C}$; mean values of measurements made every $15 \mathrm{~min}$ for $6 \mathrm{~h}$. $\mathrm{n}$ : number of measurements. Probabilities according to Student t-test

\begin{tabular}{|lcccc|} 
& $\mathrm{n} \quad \begin{array}{c}\text { Oxygen uptake } \\
\mathrm{ml} \mathrm{O} \mathrm{g}^{-1} \mathrm{~h}^{-1}\end{array}$ & SE & Probability \\
\hline Aerial & 224 & 0.0972 & 0.0041 & $<0.0001$ \\
Aquatic & 231 & 0.1412 & 0.0027 & $<0.0001$ \\
\hline
\end{tabular}

\section{DISCUSSION}

Coenobita scaevola is basically a nocturnal animal: during daytime it either finds refuge in crevices in rocks or digs into the sand. The shelter never exceeded $30 \mathrm{~m}$ from the high water line.

Temperature measurements show that the body temperature of the crabs is identical to, or very close to, ambient. In our measurements we found that the temperature inside the burrow reached 31 to $33^{\circ} \mathrm{C}$ while the air temperature outside the refuge was higher by $6 \mathrm{C}^{\circ}$, i. e. $39^{\circ} \mathrm{C}$. It should be mentioned that higher temperatures have been recorded in Elat but were not encountered during the present study. In the late hours of the afternoon, when air temperature outside the shelter started to drop, temperature inside the refuge continued to rise due to conduction from the upper heated layers of sand which reached temperatures as high as $55^{\circ} \mathrm{C}$ (Table 1; Fig. 4), or from the heated surrounding rocks. At about sunset, as the temperature outside the shelter had fallen below that inside, the crabs emerged from their refuges. At that time, the temperature of their bodies was higher than that of the air, and the exposure caused their body temperatures to drop. Body temperatures of crabs exposed to direct solar radiation (Table 1 ) rose markedly and between 11:00 h and 12:30 h crabs directly exposed to radiation died. However, all crabs exposed to air outside the burrow, but protected from direct radiation, survived.

It is evident that the crevices or burrows provide thermal refuges as well as protection from radiation. This habitat is also more humid than the outside. Due to difficulties with measuring in confined spaces, we could not establish a consistent and clear picture of the changes in relative humidity inside a crevice, but in the few measurements made it was found that in the mornings and in the late afternoons the relative humidity inside the burrow reached $100 \%$. Powers \& Cole (1976) found that also for Uca panacea, burrows provide a heat refuge.

Thermoregulation in Coenobita scaevola is behavioural, avoiding heat by search of a suitable thermal refuge during the daytime, but becoming active at night. The triggers for leaving the refuge at night cannot be explained as a reaction to changes in the light intensity, since during daytime the crabs are in the darkness of their burrows. Moreover, in a few cases at Ras Muhamad we observed crabs leaving their shelters early in the afternoon, and in the laboratory crabs were active in the daytime.

Although in the field thermoregulatory ability could not be demonstrated, under laboratory conditions, in a flow of dry air, some degree of thermoregulation was found (mean $\mathrm{T}_{\mathrm{a}}-\mathrm{T}_{\mathrm{b}}=1.4 \pm 1.0 \mathrm{C}^{\circ}$, Table 2). These experiments demonstrate that the shell decreases water loss and in consequence also the thermoregulatory capacity of the crabs. These differences were higher in hermit crabs without shells $\left(\mathrm{T}_{\mathrm{a}}-\mathrm{T}_{\mathrm{b}}=\right.$ $2.3 \pm 1.9 \mathrm{C}^{\circ}, \mathrm{n}=14$; Table 2). These results are in agreement with the water loss experiment (Table 3) and with the findings of McMahon \& Burggren (1979) that retention of the shell is important in reduction of water loss. No differences between body temperature and air temperature are demonstrated when the hermit-crabs retracted into their shells and used their chelae as an 'operculum' to seal the shell opening. The high standard deviations in crabs with shells can be attributed to differences in shell sealing, in activity, and to different amounts of water kept inside the shell. Coenobita spp. are known to collect water in their shells (Gross 1964, de Wilde 1973, McMahon \& Burggren 1979). Gross (1964) found that out of 26 individuals of $C$. perlatus from a wooded area, only 5 did not contain water in their shells. In the present study most of the crabs collected at the beginning of the night had dry shells; after emerging from their day refuge they went to the sea to fill their shells.

Differences in thermoregulatory ability and in water losses between dead and live crabs were found. Although these differences are significant $(p<0.0005)$, it should be kept in mind that only 2 specimens could be sacrificed for the experiments with dead crabs. Herreid (cited by Bliss 1968) observed that water loss in dead terrestrial crabs is only 75 to $95 \%$ of that observed in living crabs. These differences suggest that water loss by live crabs is not a purely passive process. De Wilde (1973) assumed that subtegumental glands in the abdomen of Coenobita clypeatus are involved in regulation of water loss: evidence for this assumption has not been found. Active thermoregulation by spreading gill water over the carapace was demonstrated by Fishelson (1983) in the semiterresterial crab Dotilla sulcata from the Red Sea.

The lower rate of water loss in Coenobita scaevola with shells demonstrates the importance of the shell in water conservation. Reese (1969) and McMahon \& Burggren (1979) suggest that the ability of hermit crabs to survive in the intertidal zone or terrestrial environ- 
ment is also determined by the aquatic microhabitat retained within the gastropod's shell. De Wilde (1973) suggested that water conservation is determined by the shell and the operculum

The difference between water loss from animals with and without shells is only $10.8 \%$ (Table 3 ) suggesting a low efficiency of sealing of the shell by the operculum. Volker (1979) deduced, from his morphological observations on aquatic hermit crabs, that the ability to construct a solid operculum is not an adaptation to terrestrial life as it is also found in hermit crabs living in water.

The gills are a potential area of water loss, and if so, a reduction in the gill surface area will also reduce the water loss (Gray 1957). Pearse (1929) and Cameron (1981) showed that in crabs a reduction in the number of gills is associated with the transition to terrestrial life: Pagurites puncticeps, which does not leave the water, has 26 gills; Calcinus sulcatus, an occasional invader into the intertidal zone, also has 26 gills; while Clibanarius tricolor, an intertidal species, has only 18 gills. In Coenobita diogenes, a terrestrial hermit crab, there are only 14 gills, the same number as in Coenobita scaevola. The surface areas of gills of 16 brachyuran crabs was studied by Gray (1957). Cameron (1981) studied 2 other crabs, including Birgus latro. A tendency toward reduction in gill area from aquatic to intertidal and land species was demonstrated. The highest value of $1367 \mathrm{~mm}^{2} \mathrm{~g}^{-1}$ was found in Callinectes sapidus (Portunidae). In the ghost crab Ocypoda albicaus the surface area of the gills is only 375 $\mathrm{mm}^{2} \mathrm{~g}^{-1}$. The value found in the present study is even lower, $122.5 \mathrm{~mm}^{2} \mathrm{~g}^{-1}$, but higher than those found by Cameron (1981) for Cardiosoma carnifex and B. latro, which were 80 and $12 \mathrm{~mm}^{2} \mathrm{~g}^{-1}$, respectively. On the basis of its small gill surface area it can be assumed that $C$. scaevola is well adapted to terrestrial life.

When exposed to air the gill lamellae may collapse or clump together. The thickening of the gills cuticles and swelling of the dorso-lateral margins (Fig. $5 \& 6$ ) in Coenobita scaevola increases the rigidity of the gills, and keeps the gill lamellae apart. Copeland (1968) observed similar morphological structures in the gills of the terrestrial brachyuran Gecarcinus lateralis, and in Cardiosoma camifex and Birgus latro. In Geocarcinus lateralis and Geocaridea lalandii gill leaflets are kept apart by a series of projections (Cameron 1981). Holthuisana transversa also has swellings on the marginal canal of the lamellae which presumably serve to maintain regular spacing (Taylor \& Greenaway (1979). However, these authors assume that in $H$. transversa the swellings are in order to space the lamellae in water rather than to prevent collapse in air. The thickening of the cuticle and reduction of the gill surface limits oxygen absorption, but this seems to be compen- sated by the higher concentration of oxygen in air than in water, or by using additional body surfaces for oxygen absorption. High oxygen capacity of the haemolymph which facilitates $\mathrm{O}_{2}$ and $\mathrm{CO}_{2}$ exchange, found by McMahan \& Burggren (1979) in Coenobita clypeatus might also compensate for the reduction of gill surface. Harms (1932) stated that in Coenobitidae the lining of the gill chamber as well as the abdomen serve as gas exchange surfaces. Pearse (1929) removed the gills of $C$. diogenes and did not observe any damage to the crab for $1 \mathrm{wk}$. This led him to conclude that the gills are not important in gas exchange. However, in the present study, when we cut the gills of several specimens of C. scaevola, all died.

Aerial oxygen consumption in Coenobita scaevola is $0.096 \pm 0.066 \mathrm{ml} \mathrm{O}_{2} \mathrm{~g}^{-1} \mathrm{~h}^{-1}$. This value is close to but somewhat lower than that found in $C$. brevimanus, which uses $0.12 \mathrm{ml}$ in large animals, and up to $0.49 \mathrm{ml}$ $\mathrm{O}_{2} \mathrm{~g}^{-1} \mathrm{~h}^{-1}$ in small animals (Burggren 1975). Oxygen uptake was studied in various decapods (Vernberg 1956) and it was found that oxygen consumption is highest in terrestrial species and decreases as the habitat becomes more aquatic. The range of oxygen consumption found in $U_{C a}$ is 0.019 to $0.217 \mathrm{ml} \mathrm{O}_{2} \mathrm{~g}^{-1}$ $\mathrm{h}^{-1}$. Our results are within this range found for $U_{c a} \mathrm{spp}$.

Taylor \& Butler (1978) stated that small differences between aquatic and aerial respiration is an adaptation to amphibious life. Newell et al. (1972) found in Carcinus meanus, an intertidal crab normally immersed in water, that the rate of aquatic respiration is 1.3 times more than that in air. Teal \& Carey (1967) found that in Uca pugilator and U. pugnax the aquatic respiration rates are, respectively, 1.5 and 2.5 times higher than that in air. The aquatic rate of oxygen consumption of Coenobita scaevola is about 1.4 times higher than in air; these differences are close to the rate found in the intertidal crab, C. meanas (Newell et al. 1972), suggesting that the respiration system still retains some amphibious qualities. This agrees with the finding of MacMahon \& Burggen (1979) who stated that Coenobita clypeatus showed a high degree of terrestrial adaption, but the respiratory system retained aquatic tendencies which were related to the ability of the crab to carry water in the shell. Unlike other Coenobita species, C. scaevola from Sinai, in spite of its adaptation to terrestrial life, does not penetrate the land for more than a few meters, due to its dependence upon the sea for water, since the coast of the Red Sea is arid.

\section{LITERATURE CITED}

Bliss, D. E. (1968). Transition from water to land in Decapoda Crustacea. Am. Zool. 8: 355-392 
Burggren, W. W. (1975). Oxygen consumption as a function of body size in a terrestrial hermit crab Coenobita (Decapoda Paguridea). Crustaceana 28: 314-316

Cameron, J. N. (1981). Brief introduction to the land crab of the Palau Islands: Stages in the transition to air breathing. J. exp. Zool. 218: 1-5

Copeland, D. E. (1968). Fine structure of salt and water uptake in the land crab Gecarcinus lateralis. Am. Zool. 8: 417-432

Edney, E. B. (1960). Terrestrial adaptation. In: Waterman T. H. (ed.) Physiology of Crustacea, Vol. 1 Academic Press, London, p. 367-393

Fishelson, L. (1971). Ecology and distribution of benthic fauna in the shallow waters of the Red Sea. Mar Biol. 10: $113-134$

Fishelson, L. (1983). Population ecology and biology of Dotilla sulcata (Crustacea, Ocypodidae) typical for sandy beaches of the Red Sea. In: McLachlan, A., Erasmus, T. (ed.) Sandy beaches as ecosystems, Symposium Port Elizabeth. Dr. W Junk Publ., The Hague, p. 643-654

Gray. J. E. (1957). A comparative study of the gill area of crabs. Biol. Bull. Mar. biol. Lab., Woods Hole 126: 54-68

Gross, W. J. (1964). Water balance in Anomuran land crabs on a dry atoll. Biol. Bull. Mar. biol. Lab., Woods Hole 126 . $54-68$

Gross, W. J., Holland, P. V (1960). Water and ionic regulation in a terrestrial hermit crab. Physiol. Zool. 33: 21-28

Gross, W. J., Lasiewski, R. C., Dennis, M., Rudy, P. Jr. (1966). Salt and water balance in selected crabs of Madagascar. Comp. Biochem. Physiol. 17: 641-660

Harms, J. W. (1932). Birgus latro L. als Landkrebs und seine Beziehungen zu den Coenobiten. Z. Wiss. Zool. 140: $167-290$

Kesler, J. (1982). Climate of Shelomo Erea, South Sinai and Jabel Katerina Erea, In: Lachish E, Meshel, Z. (ed.) South Sinai Researches (1967-1982). Society for Protection of Nature, Tel-Aviv (Hebrew), p. 58-63

Magnus, D. (1960). Zur Okologie des Landeinsiedlers Coenobita jousseaumei Bouvier, und der Krabbe Ocypode aegyptiaca Gerstaeker, am Roten Meer. Verh. dt. zool. Ges., Bonn 316-329

McMahon, B. R., Burggren, W. W., (1979). Respiration and adaptation to the terrestrial habitat in the land hermit crab Coenobita clypeatus. J, exp. Biol. 79: 265-281

Newell, R. C., Ahsanullah M., Pye V I. (1972). Aerial and aquatic respiration in the shore crab Carcinus maenas (L.) Comp. Biochem. Physiol. 43A: 239-252
Niegerman, R. (1968). Zur Biologie und Okologie des Landeinsiedlerkrebses Coenobita scaevola Forskal am Roten Meer. Oecologia (Berl.) 1: 236-264

Pearse, A. S. (1929). Observations on certain littoral and terrestrial animals at Tortugas, Florida, with special reference to migrations from marine to terrestrial habitats. Pap. Tortugas Lab. Carnegie Inst. Wash. 391. 205-223

Powers, L. W., Cole, J. F. (1976). Temperature variation in crab microhabitats. J. exp. mar. Biol. 21. 141-157

Reese, E. S. (1969). Behavioral adaptation of intertidal hermit crabs. Am. Zool. 9: 343-359

Ron, Z. (1967). The Negev Climate. In: Survey of Eilot District. Eilot District Council, Vol 1 (Hebrew) p. 109-156

Schmidt-Nielsen, B., Schmidt-Nielsen, K. (1950). Pulmonary water loss in desert rodents. Am. J. Physiol. 162: 31-36

Shkolnik, A., Borot, A., (1969). Temperature and water relations in two species of spiny mice (Acomys). J. Mammal. 50: 245-255

Taylor, E. W., Butler, P. J. (1978). Aquatic and aerial respiration in the shore crab Carcinus maenas L. J. comp. Physiol. B 127: 314-323

Taylor, H. H., Greenaway, P. (1979). The structure of the gills and lungs of the arid-zone crab. Holthuisana (Austrothelphusa) transversa (Brachyura, Sundathelphusidae) including observations on arterial vessels within the gills. $J$ Zool., Lond. 189: 359-384

Teal, J. M., Carey, F. G. (1967). Metabolism of marsh crabs at reduced oxygen levels. Physiol. Zool. 40: 83-91

Vannini, M. (1976). Researches on the coast of Somalia, the shores and the dune of Sar Uanle 7 . Field observations on the periodical transdunal migrations of the hermit crab Coenobita rugosus Milne Edwards. Monitore zool. ital. (N. S.) Suppl. 7, 3: 145-185

Vernberg, F. G. (1956). Study of the oxygen consumption of excised tissues in certain marine decapod Crustacea in relation to habitat. Physiol. Zool. 29: 227-234

Volker, V. L. (1967). Zur Gehäusewahl des Landeinsiedlerkrebses Coenobita scaevola Forskal von Roten Meer J. exp. mar. Biol. Ecol. 1: 168-190

Volker, V L. (1969). Zur Morphologie der Scheren des Landeinsiedlerkrebses (Coenobita scaevola Forskal). Ihre Beziehung zum Gehäuseverschluß und ihre Funktion. Zoologische Beiträge 15: 203-217

de Wilde, P. A. W. (1973). On the ecology of Coenobita clypeatus in Curacao. Studies on the fauna of Curacao and other Caribbean islands 44:1-138

This paper was presented by Professor L. Fishelson; it was accepted for printing on April 15, 1985 